\title{
Axial Dispersion of Liquid Phase in. Fixed Bed of Fine Particles
}

\author{
Tomohiro Kawai, Ryuichi Egashira and Junjiro Kawasaki
}

Dept. of Chem. Eng., Tokyo Inst. of Tech., Tokyo 152

\begin{abstract}
Key Words : Fixed Bed, Fine Particle, Axial Dispersion, Peclet Number, Prepąative HPLC
\end{abstract}

Axial dispersion coefficients and Peclet numbers for fixed beds of various fine particles were measured within the range of mean particle diameter from $4.8 \times 10^{-5} \mathrm{~m}$ to $1.7 \times 10^{-4} \mathrm{~m}$, and that of Reynolds number from $1.0 \times 10^{-2}$ to 2.0 . From the experimental results, the effects of Reynolds number, particle diameter and particle size distribution on the Peclet number were investigated and a correlation was proposed. It was suggested from the results of simulation of the chromatogram for preparative HPLC that the Peclet number affected the shape of the chromatogram when the linear velocity of mobile phase was low and the adsorption coefficient was small.

\section{ナフタレン，ビフェニルおよびキシレノール異性体 の固体モル体積の測定 ${ }^{\dagger}$}

\author{
岩井芳夫・多良 剛 - 石田尾徹・荒井康彦
}

九州大学工学部 化学機械工学科 ${ }^{\dagger \dagger}$

石炭液化油成分の固体のモル体積は，たとえば超臨界 流体に対する石炭液化油成分の溶解度などの平衡物性を 推算する上で不可欠である. しかし，分子構造が複雑な 高沸点化合物であり，既存のデータはばらつきが大きい． また, 報告例む少なく，特に $25^{\circ} \mathrm{C}$ 以外の測定データは きわめて少ない，そこで本研究では，1環の芳香族で数 種の異性体を持つキシレノールと，2環のナフタレンお よびビフェニルの結晶を作製し，15〜 $35^{\circ} \mathrm{C}$ における固体 モル体積を測定した.

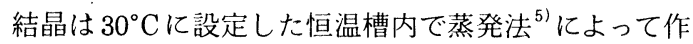
製した。まず，純エ夕ノール中に試料を飽和するまで溶 解し, エタノールを蒸発させることによって過飽和状態 をつくり, 結晶を析出させた。 また, 透明で大きな結晶 を得るため, 沪紙数枚でふたをすることにより蒸発速度 を制御した．結晶が成長するのに，15〜30日を要した。 用いた試料はナフタレン (和光純薬工業製), ビフェニ ルおよびキシレノール異性体（東京化成工業製）である.

† 1992年 4 月 20 日受理

†† 于812 福岡市東区箱崎 6-10-1

第18巻 第 6 号 $(1992)$
純度はナフタレンが $99 \%$ 以上，ビフェニルが $99.5 \%$ 以上 であり，キシレノール異性体は，それぞれ $99 \%$ 以上であ った．また，結晶化したキシレノールをガスクロマトグ ラフィで測定したところ，99.97\%以上であった。

密度 (モル体積) 測定には浮遊法 ${ }^{4)}$ を用いた。浮遊法 とは, 固体と同密度の液体（浮遊液）から間接的に試料 密度を求める方法である。本研究では浮遊液として, 塩 化ナトリウムまたは，よう化カリウム水溶液を用いた。 例として，塩化ナトリウム水溶液を用いた場合を説明す ると, まずビーカーの中に濃度の薄い塩化ナトリウム水 溶液之, 固体結晶 (約 $5 \mathrm{~mm}$ の立方体) を $20 \sim 30$ 個入れ, 所定の温度に設定した恒温槽にそのビーカーを入れた。 次に飽和塩化ナトリウム水溶液を注入することにより， ビーカー内の水溶液の濃度 (密度) を変化させ, 固体結 晶を浮遊させた。その際, 浮遊に影響を与える水中の気 泡やゴミを取り除くため, 超純水を Millipore 社製の装 置で作製し, 超音波装置 (ヤマト科学 (株) 製) により脱 気して用いた。沈積している結晶が徐々に浮遊し, 最後 の 1 個の結晶が 30 分以上同じ位置で浮遊している場合に, 
Table 1 Solid molar volumes and densities

\begin{tabular}{|c|c|c|c|}
\hline Substance & $\begin{array}{c}t \\
{\left[{ }^{\circ} \mathrm{C}\right]}\end{array}$ & $\begin{array}{c}v^{\mathrm{s}} \\
{\left[\mathrm{cm}^{3} \cdot \mathrm{mol}^{-1}\right]}\end{array}$ & $\begin{array}{c}\rho^{\mathrm{s}} \\
{\left[\mathrm{g} \cdot \mathrm{cm}^{-3}\right]}\end{array}$ \\
\hline \multirow[t]{3}{*}{ Naphthalene } & 15 & 108.68 & 1.1795 \\
\hline & 25 & 108.80 & 1.1782 \\
\hline & 35 & 109.22 & 1.1737 \\
\hline \multirow[t]{3}{*}{ Biphenyl } & 15 & 130.70 & 1.1797 \\
\hline & 25 & 131.40 & 1.1734 \\
\hline & 35 & 131.70 & 1.1714 \\
\hline \multirow[t]{3}{*}{ 2, 3-Xylenol } & 15 & 104.44 & 1.1698 \\
\hline & 25 & 104.96 & 1.1640 \\
\hline & 35 & 105.32 & 1.1600 \\
\hline \multirow[t]{4}{*}{ 2, 5-Xylenol } & 15 & 102.75 & 1.1890 \\
\hline & 20 & 102.91 & 1.1871 \\
\hline & 25 & 103.04 & 1.1857 \\
\hline & 35 & 103.34 & 1.1822 \\
\hline \multirow[t]{4}{*}{ 2, 6-Xylenol } & 15 & 107.19 & 1.1398 \\
\hline & 20 & 107.27 & 1.1389 \\
\hline & 25 & 107.39 & 1.1377 \\
\hline & 35 & 107.67 & 1.1348 \\
\hline \multirow[t]{4}{*}{ 3, 4-Xylenol } & 15 & 107.19 & 1.1398 \\
\hline & 20 & 107.32 & 1.1384 \\
\hline & 25 & 107.45 & 1.1370 \\
\hline & 35 & 107.75 & 1.1338 \\
\hline \multirow[t]{4}{*}{ 3, 5-Xylenol } & 15 & 109.45 & 1.1162 \\
\hline & 20 & 109.53 & 1.1154 \\
\hline & 25 & 109.66 & 1.1141 \\
\hline & 35 & 110.00 & 1.1107 \\
\hline
\end{tabular}

浮遊液と結晶固体は同密度であるとした。乙れは, 空孔 などがある不完全な結晶は密度が小さく, さきに浮遊し て液界面に行き, 完全な結晶に近いほど密度が大きく, 後で浮遊するからである，最後に，その浮遊液の密度を ピクノメーターを用いて測定した。 ビーカー内の水溶液 の温度の精度は土 $0.1^{\circ} \mathrm{C}$ であり，データの再現性は $0.03 \%$ であった。

得られた $15 \sim 35^{\circ} \mathrm{C}$ における固体モル体積の測定結果を Table 1 に示す. また参考までに, 密度に換算した結果も 示してある．液体ほどではないが，わずかな温度依存性 が見られた。 まだ，置換基の位置がかわることによりモ ル体積が異なることがわかった．本実験の温度範囲では， 固体モル体積 $v^{\mathrm{s}}\left[\mathrm{cm}^{3} \cdot \mathrm{mol}^{-1}\right]$ は次式で表される.

$$
v^{\mathrm{s}}=\frac{M}{a-b \cdot t}
$$

ここで, $t$ は温度 $\left[{ }^{\circ} \mathrm{C}\right], M$ は分子量, $a, b$ は定数である. 各物質に対する $a$ と $b$ の值を Table 2 に示し, さらに実 测值，文献值 ${ }^{1)}$ と Eq. (1) による計算結果を Fig. 1亿示す. ナフタレンの報告例は多いが，類似の方法で測定した文 献值 ${ }^{3)}\left(23.9^{\circ} \mathrm{C}\right)$ との差は $0.1 \%$ であった. また, ビフェ二 ルについては，文献值 ${ }^{1,3,6,7)}$ の図示は略すが，本実験值 とは差が11〜36\%あり，かなり大きかった。 さらに 5 種
Table 2 Coefficients $a$ and $b$ in Eq. (1)

\begin{tabular}{|c|c|c|}
\hline Substance & $\begin{array}{c}a \\
{\left[\mathrm{~g} \cdot \mathrm{cm}^{-3}\right]}\end{array}$ & $\begin{array}{c}b \times 10^{4} \\
{\left[\mathrm{~g} \cdot \mathrm{cm}^{-3} \cdot{ }^{\circ} \mathrm{C}^{-1}\right]}\end{array}$ \\
\hline Naphthalene & 1.1844 & 2.9 \\
\hline Biphenyl & 1.1852 & 4.2 \\
\hline 2, 3-Xylenol & 1.1769 & 4.9 \\
\hline 2, 5-Xylenol & 1.1940 & 3.4 \\
\hline 2, 6-Xylenol & 1.1438 & 2.5 \\
\hline 3, 4-Xylenol & 1.1444 & 3.0 \\
\hline 3, 5-Xylenol & 1.1208 & 2.8 \\
\hline
\end{tabular}

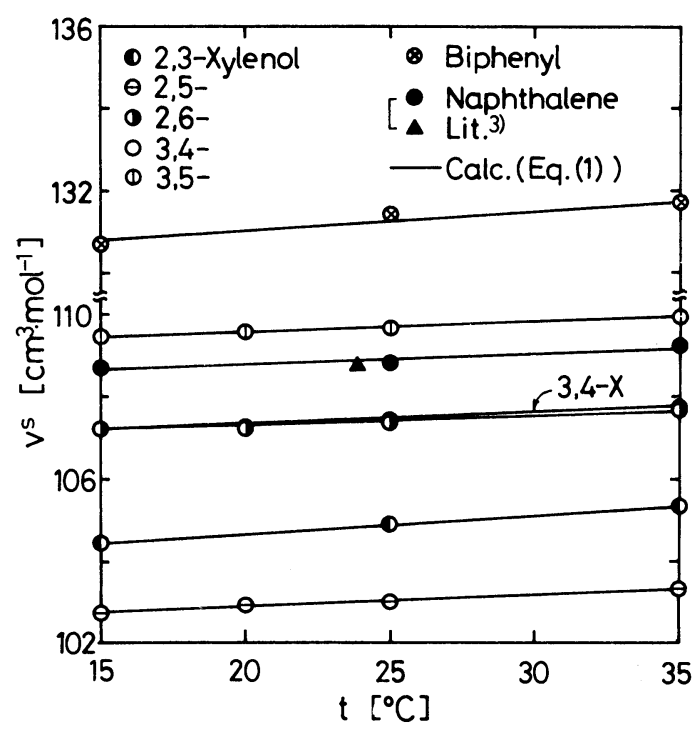

Fig. 1 Solid molar volumes of naphthalene, biphenyl and isomeric xylenols

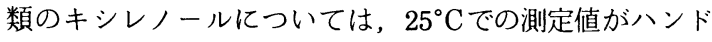
ブック ${ }^{1)}$ 亿報告されているが，本実験值との差の平均は $0.19 \%$ でよく一致している. しかし，他の文献値 ${ }^{2,7)}$ はば らついており，本実験值との差は15～20\%あり，かなり 大きかった，乙のように，固体モル体積は測定者により かなりの偏倚がみられる、またほとんどの文献值は本実 験值よりあ大きい。乙れは，文献で用いられた試料は完 全な結晶ではなく，空孔などが含まれていたためと思わ れる. 本研究で使用した結晶は 15〜30日かけて作ったも のであり，結晶状態はきわめて良好で, 固体モル体積の データあ信頼できるものと思われる.

\section{Nomenclature}

$$
\begin{aligned}
a & =\text { constant } \\
b & =\text { constant } \\
M & =\text { molecular weight } \\
t & =\text { temperature }
\end{aligned}
$$$$
\left[\mathrm{g} \cdot \mathrm{cm}^{-3}\right]
$$$$
\left[\mathrm{g} \cdot \mathrm{cm}^{-3} \cdot{ }^{\circ} \mathrm{C}^{-1}\right]
$$ 
$v^{\mathrm{s}}=$ solid molar volume $\quad\left[\mathrm{cm}^{3} \cdot \mathrm{mol}^{-1}\right]$

$\rho^{\mathrm{S}}=$ solid density

$\left[\mathrm{g} \cdot \mathrm{cm}^{-3}\right]$

\section{Literature cited}

1) Asahara, T., et al. (ed.): "Yozai Handbook", Kodansha Scientific, Tokyo (1976)

2) Beilstein, F.K.: "Handbuch der Organischen Chemie 4 th ed.", Springer, Berlin (1978)
3) Hendricks, S.B. and M.E. Jefferson: J. Opt. Soc. Am. 23, 299 (1933)

4) Nihon Kagaku Kai(ed.): "Shin Kagaku Jikken Koza 1 [ I] ", Maruzen, Tokyo (1975)

5) Nihon Kagaku Kai(ed.): "Shin Kagaku Jikken Koza 1[II]", Maruzen, Tokyo (1975)

6) Schmitt, W.J. and R.C. Reid: J. Chem. Eng. Data, 31, 204 (1986)

7) Weast, R.C. and M.J. Astle: "CRC Handbook of Chemistry and Physics”, CRC Press. (1982)

\title{
Measurement of Solid Molar Volumes of Naphthalene, Biphenyl and Isomeric Xylenols
}

\author{
Yoshio Iwai, Tsuyoshi Tara, Toru Ishidao \\ and Yasuhiko Arai
}

Dept. of Chem. Eng., Kyushu Univ., Fukuoka 812

Key Words : Physical Property, Molar Volume, Density, Solid State, Flotation Method, Naphthalene, Biphenyl, 2,3-Xylenol, 2,5-Xylenol, 2,6-Xylenol, 3,4-Xylenol, 3, 5-Xylenol

The solid molar volumes of naphthalene, biphenyl, 2, 3-xylenol, 2, 5-xylenol, 2, 6 xylenol, 3,4-xylenol and 3,5-xylenol were measured from 15 to $35^{\circ} \mathrm{C}$, using a flotation method, and the results obtained were compared with the literature values.

\section{低密度粒子を含む三相流動層の流動・物質移動特性 に及ぼす微量アルコールの影響 ${ }^{\dagger}$}

\section{宮原敏郎・李 明炆}

\section{岡山大学工学部 精密応用化学科 ${ }^{\dagger \dagger}$}

著者らは, これまでの三相流動層はガラスビーズを代 表とし，比較的密度の大きい粒子を用いて検討されてき たことから，ポリスチレン，ナイロン，活性炭粒子のよ うな密度の小さい粒子を用い物質移動特性 ${ }^{11)}$ ，混合特 性 $^{12)}$ ，気泡特性 ${ }^{13)}$ を検討してきた。しかし実際のプロセ スでは系が界面的に污染された場合が多く，水溶液中の 界面污染物質は微量でも流動特性や物質移動特性に大き く影響するてとが指摘されている ${ }^{4,211}$. この理由を Scriven ら ${ }^{19.1}$ は界面污染物質が気液界面での界面張力勾配を生じ る Marangoni 効果によるものと説明している. アルコ

\footnotetext{
† 1992年 5 月 25 日受理 ; 化学工学会岡山大会 (岡山, 1991年 7 月）にて発表

†† テ700 岡山市津島中 3-1-1
}

ールはこのような界面污染物質の一例である。アルコー ル添加の諸物性に及ぼす影響についてはてれまで気泡塔 に対しては多い ${ }^{1,2,6,15,211}$. たとえばKelkar ら ${ }^{61}$ は炭素数 1〜4のアルコールを用い気泡塔のガスホールドアップ を検討している. しかし気泡塔に対する研究とは対照的 に三相流動層に対する研究は少なく ${ }^{14)}$ ，特に低密度粒子 を含む三相流動層に対する研究は見あたらない．

本研究では気液界面污染物質の一例として液中に微量 のエタノールを添加し，低密度粒子を含む三相流動層の ガスホールドアップ，層頂を離脱する気泡の大きさ，混 合拡散係数および物質移動容量係数を実験的に検討し， 非污染系の結果と比較検討した。 